\title{
Gastronomi Turizminde Konya Yöresel Yemeklerinin Tarihsel Gelişim Süreci
}

\author{
Birsen Bulut Solak ${ }^{1^{* *}}$ Vedat Eken ${ }^{2}$ (iD \\ ${ }^{1}$ Selçuk Üniversitesi, Turizm Fakültesi, Konya, Türkiye, birsenbulut@selcuk.edu.tr, ORCID: 0000-0003-1583-1504 \\ ${ }^{2}$ Selçuk Üniversitesi, Ali Akkanat Meslek Yüksekokulu, Konya, Türkiye, vedateken@selcuk.edu.tr, ORCID:0000-0002-8733-2387
}

Öz

Selçuklu Devleti döneminde başkent olan Konya, birçok medeniyete ev sahipliği yapmış ve Mevlana'nın diyarı olarak hafızalarda yer edinmiş, kültür ve tarih şehri özelliğinin yanı sıra yöreye özgü lezzetli yemekleriyle Türk Mutfağının gelişimine büyük katkı sağlamıştır. Buna rağmen Konya, tanıtım ve pazarlama sıkıntılarından dolayı gastronomi turizm sektöründe hak ettiği değeri tam olarak görememiştir. Bu çalışmanın amacı, şehrin gastronomi turizminde öne çıkan ve/veya çıkabilecek bazı önemli yöresel yemeklerini tarihi gelişim süreci içinde derleyerek aktarmaya çalışmaktır. Bu amaçla, Neolitik çağa ait Çatalhöyük kazılarından elde edilen bulgulardan başlanarak, günümüze kadar Anadolu'da hüküm sürmüş medeniyetlerin delil niteliğindeki yazılı kaynakları incelenmiş ve Konya'daki gastronomi turizm değerleri incelenerek bu çalışmayla aktarılmaya çalışılmıştır. Zengin yemek kültürüne sahip olan Konya mutfağı, gastronomi turizmi açısından değerlendirildiğinde yemeklerin tahıl, et ve sebze ağırlıklı olduğu, bunların ana yemek bileşenlerinin temelinde önem arz ettiği tespit edilmiştir. Konya mutfağı ayrıca yöresel yemekleriyle gastronomi turizmi açısından bölge ekonomisine katkı sağlamaktadır. Bu derlemenin ışığında Konya Mutfağına özgü yemeklerin, gastronomi turizmi üzerine yapılacak yeni çalışmalara yön verebileceği düşünülmektedir.

Anahtar Kelimeler: Gastronomi, Konya Mutfağı, Yemek, Yöresel Yiyecekler

\section{Historical Development Process of Traditional Konya Meals in Gastronomy Tourism}

\section{Abstract}

Konya, the capital of the Seljuk State, hosted many civilizations and remembered as Mevlana's region, and contributed greatly to the development of Turkish Cuisine with its cultural and historical city features as well as its delicious local meals. Nevertheless, it cannot fully see the deserved value in the gastronomy tourism sector because of the promotion and marketing difficulties of Konya. The purpose of this study was to compile some important local known meals of the Konya cuisine related to gastronomy tourism during historical background. For this purpose, starting from the findings obtained from Catalhoyuk excavations in the Neolithic Age, the study of the evident written sources of the civilizations ruled in this geography until now, and the gastronomic tourism values in Konya, the importance of the Konya cuisine, which was one of the main components of Turkish cuisine with rich food cultures. When Konya cuisine with rich food culture was viewed in terms of gastronomy tourism, it was determined that the meals are predominantly cereal, meat and vegetables. These foods were important on the basis of the main meal ingredients. Additionally, the local meals of Konya have significantly affected the region's economy in terms of gastronomy tourism. In the light of this review, it is thought that it may benefit future studies on gastronomy tourism from a perspective.

Keywords: Gastronomy, Konya Cuisine, Meal, Local Foods

\section{Önerilen Atıf/Suggested Citation}

Bulut Solak, B. ve Eken, V. (2021). Gastronomi Turizminde Konya Yöresel Yemeklerinin Tarihsel Gelişim Süreci. Güncel Turizm Araştırmaları Dergisi, 5(2), 371-383.

**Sorumlu yazar e-posta: birsenbulut@selcuk.edu.tr 


\section{GíRiş}

Toplumda yemek tüketimine bakıldığında yeme ile ilgili olarak bireyler arasında birtakım farklı düşünceler olsa da bireyin yaşamını sürdürebilmesi için zorunlu bir eylem, vazgeçilemez bir olgu ya da sosyallik olarak değerlendirilebilen bir alışkanlık olduğu ortaya çıkmaktadır. Orta çağdan günümüze ulaşarak uygulanmakta olan toplu beslenme sistemi, teknolojik gelişmeler, kentleşme ve sanayileşme ile doğru orantıda gelişim göstererek yaşantımızın değerli bir parçası olmuştur (Çalışkan, 2013: 41; Solak-Bulut, 2016: 2). Buna ek olarak, devamlı gelişmekte olan turizm sektöründe farklılık arayışına, boş zamanların değerlendirilmesine yönelik bir faaliyet haline gelen ve benzersiz tüketim tecrübelerinin peşinde olan gastronomi turizminin ortaya çıkmasını sağlamıştır (Kastenholz, Davis ve Paul, 1999: 355; Gyimothy, Rassing ve Wanhill, 2000: 372; Joppe, Martin ve Waalen, 2001: 255). Gastronomi turizmi, ayrica gastronomi hareketliliğide ifade etmektedir. Turistlerin yöresel yiyecek ve içecekleri tatmak, yöresel yeme içme kültürünü öğrenmek ve deneyimlemek amacıyla yaptıkları seyahatlerin hepsi bu kapsamda değerlendirilmektedir (Kivela ve Crotts, 2005; 2006).

En popüler turizm çeşitlerine alternatif olan gastronomi turizmi, tüm destinasyonları destekleyecek niteliklere sahip ve destinasyon seçiminde önemli bir seçim unsuru olduğu düşünülmektedir (Shenoy, 2005).

Günümüzde her mutfağın kendine özgü bir tarihi ve bu tarihi yansıtan özellikleri bulunmaktadır. Mutfakların sahip olduğu bölgeye mahsus yöresel yiyecekler ise, bu mutfakları diğerlerinden ayırt eden temel özelliklerdir (Ertaş, Bulut-Solak ve Kılınç, 2017: 53). Bir bölgenin kültürel tanıtımında en önemli araçlardan birisi şüphesiz o bölgenin yöresel yemekleridir (Kastenholz, Davis ve Paul, 1999: 355; Gyimothy, Rassing ve Wanhill, 2000: 372; Joppe, Martin ve Waalen, 2001: 255). Konya, yüzylllar boyunca birçok medeniyeti topraklarında barındırmış tarihi ve kültürel zenginliklere sahip, özellikle Selçuklu ve Mevlevi mutfak kültürünü yansıtan bir Anadolu şehridir. Gastronomi turizmi için önemli değerleri olan Konya'nın yöresel yemeklerinin çeşitliliği ve lezzeti, şehri ziyaret eden gastronomi turistlerine her daim gelebilecekleri bir gastronomi şehri olma yolunda ilerletmektedir (Yetiş, 2015: 14). Bu amaçla, her yıl Konya'ya gelen yerli ve yabancı misafirlerin destinasyon ziyareti ile birlikte farklı lezzetleri arama arzusu, Konya'da gastronomi turizminin bir şekilde oluşmasına neden olmuştur. Bu durum Konya'yı zaman içinde yöresel mutfağın yansıtıldığı önemli gastronomi destinasyonlarından biri haline getirmiştir (Seçim ve Esen, 2020: 282).

Konya şehrinin tarihi eski neolitik çağa dayanmakta olup, Hitit, Roma-Bizans, Selçuklu ve Osmanlı dönemlerinden etkilenmiştir. Anadolu yemek kültürünün birçok özelliğine sahip olan Konya mutfağı, tarih boyunca kuşaktan kuşağa aktarılarak kendine has yapısıyla Türk mutfak kültüründeki yerini almıştır. Konya sınırları içerisinde bulunan eski tarihi yerleşim yerlerinden olan Çatalhöyük'te yapılan kazılarda (M.Ö. 6000-5000) elde edilen mutfak araç-gereçlerindeki bulgur ve mercimek kalıntıları, Konya mutfağının geçmişine yönelik 8000 yıllık belge olma niteliğini taşımaktadır. Bu nedenle, günümüzde Konya'da yapılan mercimek yemeği 
ve mercimekli bulgur pilavının geçmişten günümüze kadar geldiği düşünülmektedir (Halıc1, 2011). Bu nedenle Konya, Anadolu yemek kültürünün vazgeçilmez yerleşim yerlerinden birisi olma özelliğini taşımaktadır (Yetiş, 2015: 13). Selçuklu dönemine ait Konya mutfağı, yemekleriyle Türk mutfağının temel yapı taşlarını oluşturmuştur. Yöresel yemeklerine ilaveten, Selçuklu dönemindeki sofra düzeni, pişirme yöntemi ve teknikleri, mutfak araç-gereçleri, servis düzenleri ve eşsiz mutfak mimarisiyle Anadolu coğrafyasının lezzet öncüsü olmuştur. Selçuklu ve Beylikler döneminin yazılı eserlerinde, Konya mutfak ve yemek kültürüne rastlanılmaktadır. Bu eserler incelendiğinde, yemek yapımında kullanılan bazı yiyecekler ile birlikte Konya yemeklerine yer verildiği görülmektedir. Dede Korkut hikâyelerinde bahsedilen yoğurt, ayran, peynir ve yahni gibi yiyecekler, Konya'nın yiyecekleri arasındadır (Halıc1, 2011). Bunlara ilaveten Mevlâna Celaleddin Rumi'nin aşçısı Ateş-baz-1 Veli, dünyada adına anıt mezar yaptırılan ilk aşçı olma özelliğine sahip olmakla birlikte, Konya'da 13. yüzyılda mutfağa ve bir aşçıya verilen değerin önemini ortaya koymaktadır (Halıcı, 2005; Ertaş, Bulut-Solak ve Kılınç, 2017: 55). 1960’lı yıllara kadar klasik özelliklerini taşıyan Konya mutfağında, eski yemekleri bilen kişilerin az sayıda olması, yemeklerde kullanılan malzemelerin değişmesi, ekonomik zorluklar ve teknolojik yenilikler Konya mutfağındaki klasik dokuda kısmen de olsa birtakım değişikliklere sebebiyet vermiştir.

Çatalhöyük kazılarında elde edilen mercimek ve bulgur kalıntıları ile başlayan ve Selçuklulardan günümüze gelen yöresel ev yemekleri, standartlaşmış sofraları ve kendine özgü özellikleriyle Konya mutfağı, Anadolu kültürünün en özel mutfaklarından birini ortaya çıkarmıştır. Birbirinden farklı çorba çeşitleri, et ve sebze yemekleri, kebap çeşitleri, mantar ve ot yemekleri, meyve yemekleri, zeytinyağlılar, salatalar, pilav ve makarnalar, börekler, hamur tatlıları, sütlü tatlılar, meyve-sebze tatlıları, ekmekler, ekmekten yapılan yiyecekleri bünyesinde barındırmaktadır. Konya mutfağında hayvansal yağ olarak sadeyağ, tereyağ1, kuyruk yağ1 ve içyağ1, bitkisel yağlardan zeytinyağı, susam, ayçiçeği ve mısırözü yağları kullanılmaktadır (Halıcı, 2005; Büyükşalvarc1, Şapcılar ve Yılmaz, 2016: 166). Bunlara ilaveten Çatalhöyük yerleşim yerinin Konya il sınırları içerisinde bulunması, Konya'nın kuzine kültürünün gelişmesine önemli ölçüde katkı sağlamıştır. Anadolu'da başkentlik yapmış olan Konya şehrinin, Selçuklu Devleti tarafından fethedilmeden önceki yemek kültürü ile alakalı kapsamlı bir bilgi bulunmasa da yemeklerin tahıl, özellikle hamur işleri, et ve sebze ağırlıklı olabileceği düşünülmektedir (Odabaşı, 2001). İnsanların göçebe hayattan yerleşik yaşama geçişinde toprağı tarımsal faaliyetlerde kullanması, toprakta sebze meyve yetiştirilmesi ve bu ürünlerin depolanmasını sağlayan gelişmeler Anadolu'da meydana gelmiş ve buradan tüm dünya topluluklarına yayılmıştır. Bu bağlamda verimli Anadolu topraklarında yiyecek çeşitliliği ve üretimi ortaya çıkmıştır (Sürücüoğlu ve Özçelik, 2007). Böylece Anadolu'da turizm destinasyonundaki yerel Konya mutfak yiyeceklerine turistlerin ilgisinin her geçen gün artmasına sebebiyet vermiştir. 


\section{Kavramsal Çerçeve}

Mevcut bilimsel kaynaklar (Halıc1, 2011; Büyükşalvarcı, Şapcılar ve Yılmaz, 2016; Ertaş, Bulut-Solak ve Kılınç, 2017; Seçim ve Esen, 2020) araştırıldığında, Konya mutfağının yöresel yemeklerinin içeriğiyle ilgili yeterli düzeyde araştırma yapılamamış olmasından ve ekonomik ve çevresel faktörlerin etkisiyle yemek reçetesinde kullanılacak malzemelerdeki değişikler ve Konya yöresel yemeklerinin yapılışını bilen kişi sayısının azalmasından dolayı bu çalışmanın yapılmasına karar verilmiştir. Ayrıca Konya mutfağının gastronomi turizmi açısından tanıtım yetersizliğinin olduğu düşünüldüğünden dolayı çalışma, ilgili alan yazıları taranarak hazırlanmıştır.

\section{Orta Asya Döneminin Konya Mutfağına Etkisi}

M.Ö. 200 y1llardan beri Orta Asya dönemindeki Türkler, bozkır yaşam düzeni kapsamında çoğunlukla at, koyun, keçi, büyükbaş hayvanlar ve av eti olmak üzere hayvansal ürün tüketmişlerdir. Bu ürünlere ek olarak başta buğday olmak üzere arpa ve darı gibi tahıl ürünlerini mutfaklarında kullandıkları görülmüştür (Kızıldemir ve Sarışık, 2014: 192; Bilgin ve Samanc1, 2015). Süt, yoğurt, ayran ve yufka gibi yiyeceklerin, o dönemlerde Konya yöresine geldiği ve günümüzde halen tüketildiği belirtilmektedir. Orhun Abidelerinde, geyik ve tavşan etlerinin yenildiği ve ölen kişiler için ölü aşı (yemeği) verildiğinden bahsedilmekte ve günümüzde de halen ölü aşı (yemeği) verilmesi devam etmektedir. Bu nedenle, Konya mutfak ve yemek kültürünün Orta Asya'dan günümüze ulaştığı görülmektedir. (Halıc1, 2011; Bilgin ve Samanc1, 2015).

\section{Selçuklu ve Beylikler Döneminin Konya Mutfağına Etkisi}

Selçuklu mutfağının tarihine bakıldığında 11. yüzyılın sonlarına kadar uzandığı ifade edilmektedir. Göçebe geleneğinin bir sonucu olarak hayvansal ürünlerden, yerleşik hayatın geçim kaynağ olmuştur. Bu dönemde yemeklerin pişirildiği mutfaklar, yiyenlerin sosyal konumları ile farklılıklar göstermektedir. Devlet adamlarının mutfakları daha görkemli iken, halk mutfağ 1 daha sade görünümlü olmaktadır (Bilgin ve Samanc1, 2015). Bu döneme ait yazılı eserlerde Konya mutfağı yemek kültürü ile ilgili bilgiler yer almaktadır. Kaşgarlı Mahmud'un, Divan-ü Lügat-it Türk isimli eserinde Konya yöresel yemeklerine dair bilgilere yer verilmiştir. Özellikle tutmaç, yufka, yoğurt, ayran, bekmes, bulgama (bulamaç), kavut (helva) ve çörek birkaçını oluşturmaktadır. Kaşgarlı Mahmud, Karlukça dilinde soğut veya suğut adı verilen peynirin ekşi sütten yapıldığını söylemiştir (Koz, 2002) ve koyun sütünden yapılan yoğurdun kurutulmasılyla kurut elde etmişlerdir (Ögel, 1978). Buğdaygiller familyasında yer alan darı, Anadolu'da kavrulmuş bir şekilde tüketildiği tespit edilmiştir (Ögel, 1978). Mutfak araçgereçleriyle burilemek gibi pişirme tekniklerine ayrıca değinilmiştir. Yer sofraları ve ikram usullerinin, günümüz Konya mutfağında aynı şekilde devam ettiği görülmektedir (Halıc1, 2011; Ertaş, Bulut-Solak ve Kılınç, 2017: 56). 


\section{Anadolu Selçuklu Döneminde Konya Mutfağı}

Konya'nın Selçuklu Döneminde 1097 yılında başkent olması, Konya mutfağının gelişmesinde önem arz etmektedir. Anadolu'da faaliyet göstermiş olan Selçukluların mutfak kültürü, Mevlevi mutfak kültüründen önemli ölçüde etkilenmiştir (Batu, 2016. 29; Ertaş, Bulut-Solak ve Kılınç, 2017: 57). Anadolu' da hayat bulmuş ilk medeniyetlerin mutfaklarında daha çok tahıl ve et olduğu görülmektedir. Türkler de Orta Asya'dan benzer şekilde bir yemek kültürüyle Anadolu'ya gelmişlerdir. Anadolu Selçuklu Devleti döneminde Türklerin tüketim ve kuzine kültürü, bu topraklara ulaşmadan önce benimsemiş oldukları ihtiyaçlarını karşılarken kullanmış oldukları araç-gereçleri göç esnasında getirdikleri ve Anadolu topraklarına ulaştırdıkları görülmüştür. Selçuklu Anadolu'sunda Türklerin yeme-içme kültürünün, Anadolu topraklarında yetişen ürünlerle harmanlandığı ve birçoğunun günümüze kadar ulaştığı görülmektedir (Uzunağaç, 2014). Anadolu Selçuklularının beslenme alışkanlıklarında ağırlıklı olarak et ve tahıl tüketiminin fazla olduğu görülmektedir. Selçuklu Türkleri, hayvanların etinden, sütünden, yününden ve derisinden yararlanmışlardır. Daha çok sığır, keçi ve koyun gibi küçükbaş ve büyükbaş hayvanları besledikleri tespit edilmiştir. Türkler, kesilmiş hayvanların etine ilaveten sakatatlarına kadar etin her yerini toprak tandır fırınlarda pişirir ve sofrada ikram ederlerdi. Kesilen hayvandan kalmış etler ise küçük bir şekilde doğranır, pişirilir, üzerine ise içyağı eritilerek dökülür ve daha sonra tüketilmek üzere büyük kaplarda saklanırdı. Bir diğer saklama yöntemi ise, kemikli etin gün ışığında kurutulup saklanarak genellikle kış yemeklerinde kullanıldığı belirtilmektedirler (Akın, Özkoçak ve Gültekin, 2015: 42; Büyükşalvarcı, Şapcılar ve Yılmaz, 2016: 166). Selçuklular döneminde hem iç yağ hem de yemeklik yağ müşterek olarak kullanırdı (Ögel, 1978).

Anadolu Selçuklularının sade ve abartıdan uzak yaşam tarzları, yapmış oldukları mimarilerine yansıdığı gibi mutfak kültürlerine de yansıdığ1 düşünülmektedir. (Düzgün ve Durlu-Özkaya, 2015: 43). Anadolu Selçuklu Türklerinde günde sadece iki öğün yemek yenir, sabahtan öğlene kadar ki saatlerde yedikleri yemeğe (kuşluk), karanlık olmadan ve bol çeşitle yedikleri yemeğe ise akşam yemeği demişlerdir (Kızıldemir ve Sarışık, 2014: 196). Selçuklu saray mutfağının halkla aynı mutfak kültürüne sahip olduğunu görülmektedir. Kaşgarlı Mahmud, Türklerin aynı şeyleri yiyip içtiklerinden bahsetmektedir. Bu yiyeceklerin başında pişirilmiş et, kurutulmuş et ve yaş dedikleri sebze yemeklerini az da olsa tükettikleri belirtilmektedir (Eken ve Bulut-Solak, 2018). Selçuklu çağının başlangıcında küle gömülerek pişirilen çörek veya ekmeğe ise kömeç adı verilmiştir. Unu yağ ile kavurduktan sonra üzerine bal veya pekmez dökülerek elde edilen helvaya kavut denilmiştir. Günümüz Konya mutfağında bir tatlı olarak yapılan höşmerim ise Selçuklular dönemine dayanmaktadır (Ögel, 1978).

\section{Mevlevi Döneminde Konya Mutfağı}

Mevlevi mutfak kültürü tarihin izleri, 13. yüzyıldan günümüze ulaşmaktadır. Mevlana'nın 13. yüzyılda mutfağa ayrı bir ehemmiyet vermesinden dolayı ortaya çıkan Mevlevi mutfak kültürü, Konya yöresinde kısmen yaşatılmaya ve sürdürülmeye 
çalış1lmaktadır (Batu, 2016: 31; Aksoy, Akbulut ve İflazoğlu, 2016: 97, 101; Ertaş, BulutSolak ve Kılınç, 2017: 69). Mevlevi yemekleri, deniz ürünleri hariç genellikle badem, nohut, bulgur, pirinç, et, patlıcan, soğan, kabak, kereviz, bal ve pekmez kullanılarak hazırlanmıştır. Mevlevilikte, gelen konuklara talepleri halinde balık ikram edildiği belirtilmektedir (Tosun, 2004: 128; Halıc1, 2007; 64-65; Ertaş, Bulut-Solak ve Kılınç, 2017: 63). Mevlevi kültüründen günümüze kadar gelen en bilinen tatlı ise badem helvasıdır (Aksoy, Akbulut ve İflazoğlu, 2016: 101). Mevlevi mutfağında suda pişirme, yağda kızartma, kuru ısıda pişirme, yağ ve su karışımında pişirme yöntemleri kullanılmaktadır (Halıcı, 2007: 42). Bunların yanı sıra Mevleviliğin birtakım sert hiyerarşik kuralları sebebiyle, Mevlevi yemeklerinin hazırlanışı diğer mutfaklara kıyasla bazı farklılıklara sahip olmuştur. Özellikle Anadolu'da 13. yüzyılda dervişlerin, mutfakta Mevlevi kültürüne özgü yemekleri pişirirken aynı zamanda sabrı, hizmet anlayışı, nefis terbiyesi, kararlılığı, adanmışlığı ve çalışkanlığı değerlendirilmiştir (Bekleyiciler, 2015: 89; Aksoy, Akbulut ve İflazoğlu, 2016: 100; Ertaş, Bulut-Solak ve Kılınç, 2017: 52; Ceylan ve Yaman, 2018: 2173).

Mevlevi yemek kültüründe sofrada oturanlar, sağ işaret parmaklarını önce dillerine, sonra ise tuza banarak tuz tadarlar ve daha sonra yemeğe başlarlardı. Yemekler sofra üzerinde ortaya konulur ve herkes aynı kaptan yerdi. Mevlevi mutfağında ana yemekten önce susuzluğu gidermek için Sirkencübin (bal ve sirke karışımı içecek) ikram edilir, daha sonra çorba servisi yapılırdı (Tosun, 2004: 132; Halıcı, 2007: 42; Soysal, 2007: 88; Ertaş, Bulut-Solak ve Kılınç, 2017). Halıcı'ya göre; Mevlevi mutfağında çoğunlukla koyun eti kullanılırken (2007), günümüzdeki Mevlevi mutfağ1 yemeklerinin yapımında tercihen dana etinin de kullanılabileceğini belirtilmiştir (Ertaş, Bulut-Solak ve Kılınç, 2017: 58). Mevlevi mutfağına özgü yemekler pişirilirken bakır kaplar kullanılmaktadır (Ertaş, Bulut-Solak ve Kılınç, 2017: 58). Mevlâna Celaleddin Rumi döneminde az ve sade malzemelerle yapılan yemekler, farklı mutfaklarda olduğu gibi Mevlevi mutfak kültürünün de değişmesine sebep olmuştur. Mevlevi mutfağında tarçın, karabiber, kimyon ve sumak gibi baharatlar kullanılmış olup, bu baharatlar Mevlâna'nın eserlerinde de kendilerine yer bulmuştur (Halıcı, 2007: 40; Aksoy, Akbulut ve İflazoğlu, 2016: 100; Ertaş, Bulut-Solak ve Kılınç, 2017: 58).

\section{Osmanlı Döneminde Konya Mutfağı}

Selçuklu Devleti döneminden kalan birçok kurum, gelenek ve görenekler, 13. yüzyıldan itibaren Osmanlı devletine mihmandar olmuştur. Bu kurumların içerisinde bulunan mutfaklar elbette büyük bir öneme haiz olmaktadır (Halıcı, 2005). Selçuklu dönemindeki Konya mutfak kültürü, Osmanlı döneminde hiçbir mimari değişikliğe ve farklılığa uğramaksızın günümüze kadar gelmiştir. Özellikle Konya'nın köylerine gidildiğinde misafirlik boyunca Selçuklu dönemine ait yeme-içme ikramlarıyla karşılaşılmaktadır (Batu, 2016: 31). Anadolu'ya giriş yapan ve buralarda durağan bir halde yaşamaya başlayan Türkler, Anadolu'da asırlardır yaşam süren birçok kavmin bırakmış olduğu tüketim alışkanlıklarını da zamanla benimseyerek yaşamlarına devam etmişlerdir (Akman, 2008). Ancak Osmanlı saray yapısında en mühim yerlerden bir tanesine sahip olan mutfak, Osmanlı saray yapılarının hayati bir 
öğesidir. Saray mutfağı sürekli farklılıklar arayan, kendini güncel tutmaya çalışan ve aynı zamanda her zaman lezzetli yemekler sunmak için emek sarf etmiştir. Türk mutfağının bu denli bir ihtişama kavuşmasında elbette ki saray mutfağında, padişahların yemeklerini pişiren aşçıların birbirleriyle rekabet etmelerinin etkisi büyüktür (Güler, 2016: 24). Osmanlı devleti döneminde mutfak kültürü saray bazında gelişmiş ve sürekli kendini geliştirmenin yollarını aramıştır. Ancak halk arasında genellikle yine eski usullerle yemekler yapılmış ve ağırlıklı olarak et yemekleri tüketilmiştir. Osmanlı devleti döneminde halk mutfağı ile alakalı kesin bilgiler bulunamamaktadır (Güler, 2016: 25). Anadolu topraklarına 15. yüzyıldan sonra getirilen domates ve patates de yeni lezzetler katmak üzere Anadolu ve Konya mutfağına kazandırılmıştır (Halıc1, 2011). Lübnan asıllı yazar Emin Maruf, Yüzüncü Ad isimli romanında, 1665 yılında Konya'da bulunan Meram bağlarında dolaşan şerbetçilerin ve kayısı suyu satıcılarının bardaklarını çınlatarak herkesi baştan çıkartan, iştahını kabartan ürünlerini sattıklarından ve duman tüten tezgâhlardan (muhtemelen seyyar kebap, köfte satıcıları) bahsetmektedir (Halıc1, 2011).

\section{Sille Mutfağının Konya Mutfağına Etkisi}

Konya ilinde bulunan Sille beldesi, tarihi zenginlikleri, kültürel etnik farklılıkları, yöreye ait lezzetli yemekleri, geçmişten süregelen örf ve adetleri ile yaklaşık 6000 yıllık bir geçmişe sahiptir (Konyalı, 1964; Bulut-Solak, 2016: 9). Sille mutfağına bakıldığında birçok medeniyetin özellikle M.Ö. Hititler ve Frigyalılar, M.S. ise Romalılar, Bizanslar, Selçuklular, Karaman oğulları ve Osmanlılar kültürlerinden izler taşımaktadır. Sille’ye özgü yöresel yemekler buğdaydan elde edilen ürünler, et ve et ürünleri, balık ürünleri, süt ve süt ürünleri önemli bir yere sahiptir. (Bulut-Solak, 2016: 2). Sille halkı, tuzlanmış balık ve havyar kurması olarak ifade ettikleri yiyecekleri, kendilerine özgü muhafaza yöntemleri ile birlikte halen kullandıkları görülmektedir. Asırlardır etnik olarak farklı yapı ve inançlara sahip olmalarına rağmen Romalılar ve yöre halkları, Sille yöresinde uyum içerisinde birlikte yaşamışlardır. Birlikte yaşadıkları süre içerisinde yiyecekiçecek alışverişlerinde bulunmaları, Sille mutfağının Roma ve Selçuklu mutfaklarının kültürel özelliklerini taşıdığını ortaya koymakta (Bulut-Solak, 2016: 9), Konya mutfağı yiyeceklerinin çeşitlenmesinde (kayısı yahnisi, calla, tandır ekmeği gibi) kısmen de olsa etkili olmaktadır (Halıcı, 2013). Bu nedenle, Sille mutfağı özellikle Roma, Selçuklu ve Osmanlı kültürlerine ve özgün yöresel ve etnik yemek çeşitliliğine sahip bir beldedir (Halıc1, 2013). Sille yemekleri hazırlanırken, farklı pişirme teknikleri kullanılmaktadır. Sille mutfağına mahsus pişirme tekniği, paça tiridine ve ekmek tandırına uygulanmaktadır. Tüm kışlık yiyecek ve içecekler, toprak küplerde muhafaza edilmektedir. Sille mutfağına özgün pekmez kazanı ve leğenleri, hamur tekneleri, hamur açma tahtası ve kekik dibeği bulunmaktadır (Halıc1, 2013). Sille çevresinde yaşayan yabani tavşan, keklik, balık gibi av hayvanlarından yapılan yemekler ayrı bir lezzete sahiptir (Sarıköse, 2009: 7-10). Sille mutfağında ayrıca tiridin 40 çeşidi yapılmaktadır (Halıc1, 2013). Günümüzde Sille'de, bu bölgede yaşayan halk tarafından ve evlerde yapılan pekmez, tandır, kuru üzüm, kuru kayısı gibi yöresel ürünlerin satışı yapılmaktadır (Bulut-Solak, 2016: 12). 


\section{Günümüz Konya Mutfağ1}

Geçmişinde birçok medeniyete ev sahipliği ve Selçuklu döneminde başkentlik yapmış olan Konya'nın, günümüz mutfak kültürünün tarihi, neolitik çağlardan başlayarak akabinde Hitit, Roma-Bizans, Selçuklu ve Osmanlı dönemlerinin etkisinde kalmıştır. Ayrıca Konya'da bambaşka bir gastronomi turizmi deneyimi sağlayan Mevlevi ve Sille mutfak kültüründeki yemeklerinde etkisi ayrıca dikkat çekmektedir.

Yerleşik hayatın ilk başladığı yer olan Konya, asırlardır tarımın da merkezi olmuş, günümüzde ise ağırlıklı tahıl üretimi yapılan bir ilimizdir. Eski Selçuklu döneminde olduğu gibi Konya hali hazırda et ve hamur işi tüketiminin fazla olduğu bir şehir olup, özellikle buğday unundan yapılan yemeklerin daha fazla tüketildiği görülmektedir. Konya mutfağının belirgin bazı yiyeceklerinden bahsetmek gerekirse bunların başında çorbalar (bamya çorbası, toyga çorbası, yoğurt çorbası, tandır çorbası vb), et yemekleri (fırın kebabı, tirit) ve hamur işinden yapılan yemekler (etli ekmek, su böreği, saç böreği, tandır ekmek vb) ve hamur tatlılar [sacrarası] unlu tatlılar [höşmerim, badem helvası]) gelecektir. Bununla ilgili detaylı bilgiler Tablo 1.'de verilmiştir.

Tablo 1. Konya'nın gastronomi turistik ürünleri

\begin{tabular}{|c|c|c|c|}
\hline Tür & Yemek adı & Reçetesi & Kaynakça \\
\hline \multirow{6}{*}{$\begin{array}{l}\frac{\pi}{\pi} \\
\frac{0}{0} \\
0 \\
0 \\
0\end{array}$} & Toyga Çorbası & Süzme yoğurt, yarma, et suyu, tereyağı, nane ve tuz & (Işık, 2006) \\
\hline & Mercimekli Ovmaç & $\begin{array}{l}\text { Yeşil mercimek, et suyu, un, sadeyağ, yumurta, nane } \\
\text { ve tuz }\end{array}$ & (Işık, 2006) \\
\hline & Bamva corbas & $\begin{array}{l}\text { Çiçek bamya, kuzu eti, kuyruk yağı, tereyağı, soğan, } \\
\text { biber salçası, domates salçası, limon suyu, tuz, su }\end{array}$ & $\begin{array}{l}\text { (Karaman ve } \\
\text { Bağcioğlu, 2014) }\end{array}$ \\
\hline & $\begin{array}{l}\text { Yoğurt (Toyga/ Tovga) } \\
\text { çorbası }\end{array}$ & $\begin{array}{l}\text { Süzme yoğurt, haşlanmış nohut, yumurta sarısı, } \\
\text { pirinç, tereyağı, et suyu, karabiber, nane, tuz }\end{array}$ & (Halıcl, 2005) \\
\hline & Tandır Çorbası & $\begin{array}{l}\text { Yeşil mercimek, nohut, kuru fasulye, tereyağı, soğan, } \\
\text { bulgur, salça, et suyu, kırmızıbiber, karabiber ve tuz }\end{array}$ & (Halıc1, 2005) \\
\hline & Arabaşı & $\begin{array}{l}\text { Tavuk eti, tavuk suyu, tereyağı, un, salça, kırmızı acı } \\
\text { pul biber ve tuz }\end{array}$ & (Işık, 2006) \\
\hline \multirow{7}{*}{ 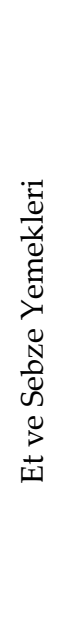 } & Firın Kebabı & Yağlı ve az kemikli et, tuz & (Işık, 2006) \\
\hline & Zülbiye & $\begin{array}{l}\text { Kuşbaşı koyun eti, arpacık soğan, sadeyağ, salça, } \\
\text { karabiber ve tuz }\end{array}$ & (Işık, 2006) \\
\hline & Kayısı Yahnisi & Kemikli koyun eti, kuru kayısı, tereyağı ve toz şeker & (Işık, 2006) \\
\hline & Sarı Erik Yahnisi & Sarı erik, koyun kıyma, tereyağı, pirinç ve toz şeker & (Işık, 2006) \\
\hline & Bütüm et & $\begin{array}{l}\text { Koyun eti, soğan, domates, sadeyağ, sivri biber, } \\
\text { patlican, su ve tuz }\end{array}$ & (Işık, 2006) \\
\hline & Calla & $\begin{array}{l}\text { Yeşil erik, sadeyağ, az yağlı koyun eti, kuru soğan, } \\
\text { salça ve tuz }\end{array}$ & (Işık, 2006) \\
\hline & Ekşili Kabak & $\begin{array}{l}\text { Asma kabağ } \text { (et kabağı), kemikli koyun eti, domates, } \\
\text { kuru soğan, sarımsak, limon suyu veya koruk ekşisi, } \\
\text { kadife yaprağı, reyhan, nane ve tuz }\end{array}$ & (Işık, 2006) \\
\hline
\end{tabular}




\begin{tabular}{|c|c|c|c|}
\hline \multirow[t]{9}{*}{ 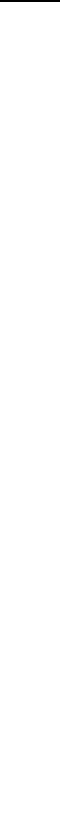 } & Çullama & $\begin{array}{l}\text { Koyun kıyma, pirinç, soğan, karabiber, un, yumurta, } \\
\text { sadeyağ ve tuz }\end{array}$ & (Işık, 2006) \\
\hline & Sündürme & $\begin{array}{l}\text { Az yağlı küflü tulum peyniri, sadeyağ, tandır ekmeği, } \\
\text { et suyu ve tuz }\end{array}$ & (Işık, 2006) \\
\hline & Etli Tatlı Kabak & Asma kabağı, yağlı koyun eti, pirinç ve şeker & (Işık, 2006) \\
\hline & Papara & Tandır ekmeği, sadeyağ, kuru soğan, et suyu ve tuz & (Işık, 2006) \\
\hline & $\begin{array}{l}\text { Tandır Kuzusu veya } \\
\text { Çebici }\end{array}$ & $\begin{array}{l}\text { Koç veya erkek keçi, domates salçası, sarımsak, soğan, } \\
\text { kırmızıbiber ve tuz }\end{array}$ & (Işık, 2006) \\
\hline & Pekmezli Havuç Yemeği & $\begin{array}{l}\text { Havuç, su, pirinç, sıvı yağ, üzüm pekmezi, limon } \\
\text { suyu, hardal, tuz, kekik, biberiye }\end{array}$ & (somatci.com, 2016) \\
\hline & Kereviz Kalyesi & $\begin{array}{l}\text { Kereviz, kemikli kuzu eti, sadeyağ, soğan, et suyu, } \\
\text { koruk suyu, tuz }\end{array}$ & (Halıc1, 2007: 134) \\
\hline & Bulamaç aşı & Soğan, kıyma, üzüm pekmezi, su & (Halıc1, 2007: 81) \\
\hline & Tirit & $\begin{array}{l}\text { Et, pide, soğan, yoğurt, sarımsak, tereyağı, salça, tuz, } \\
\text { karabiber }\end{array}$ & (Halıcl, 2005) \\
\hline \multirow{5}{*}{ 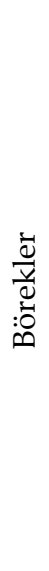 } & Su Böreği & $\begin{array}{l}\text { Börek hamuru, kıyma veya beyaz peynir, tereyağı, } \\
\text { tuz, maydonoz }\end{array}$ & (Işık, 2006) \\
\hline & $\begin{array}{l}\text { Saç Böreği } \quad \text { (Sedirler } \\
\text { Böreği) }\end{array}$ & $\begin{array}{l}\text { Az yağlı peynir, maydanoz, kuru soğan, karabiber, } \\
\text { tereyağı, un ve tuz }\end{array}$ & (Işık, 2006) \\
\hline & Etli Ekmek (Etli pide) & $\begin{array}{l}\text { Koyun kıyma, domates, yeşil sivri biber, maydanoz, } \\
\text { kuru soğan, tuz ve pide hamuru }\end{array}$ & (Işık, 2006) \\
\hline & Biçak arası & $\begin{array}{l}\text { Kuşbaşı et, domates, yeşil sivri biber, maydanoz, kuru } \\
\text { soğan, tuz ve pide hamuru }\end{array}$ & (Halıcl, 2005) \\
\hline & Çarşı Böreği & $\begin{array}{l}\text { Küflü tulum peyniri veya beyaz peynir, maydanoz, } \\
\text { kuru soğan, karabiber, yumurta, tereyağı, pide } \\
\text { hamuru ve tuz. }\end{array}$ & (Işık, 2006) \\
\hline \multirow{4}{*}{ 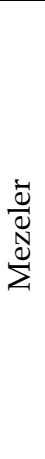 } & Cacik & $\begin{array}{l}\text { Salatalık, yoğurt, sarımsak, su, zeytinyağı, dereotu, } \\
\text { tuz }\end{array}$ & (Arsel, 1999) \\
\hline & Sarımsaklı Yoğurt & Süzme yoğurt, sarımsak, tuz, karabiber & $\begin{array}{l}\text { (Sadıkoğlu, } \\
\text { Yerlikaya, Funda } \\
\text { ve Cumalı, 1999) }\end{array}$ \\
\hline & Sumaklı Soğan Piyazı & Soğan, sumak, zeytinyağı, nar ekşisi, tuz & $\begin{array}{l}\text { (Özkanlı ve Tekin, } \\
\text { 2006: 331) }\end{array}$ \\
\hline & Patlıcan Salatası & $\begin{array}{l}\text { Patlıcan, limon, zeytinyağı, tuz, domates, sarımsak, } \\
\text { sivri biber veya çarliston biber }\end{array}$ & (Arsel, 1999: 120) \\
\hline \multirow{6}{*}{ 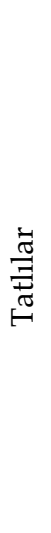 } & Katmer & $\begin{array}{l}\text { Süt, zeytinyağı, karbonat, un, yumurta, tereyağı, } \\
\text { pudra şekeri. }\end{array}$ & (Işık, 2006) \\
\hline & Kaygana & $\begin{array}{l}\text { Un, yumurta, yoğurt, karbonat, şeker, su, limon suyu, } \\
\text { sıvı yağ. }\end{array}$ & (Işık, 2006) \\
\hline & Höşmerim & Tereyağ1, un, süt, yumurta ve tuz. & (Işık, 2006) \\
\hline & Sacarası & $\begin{array}{l}\text { Un, zeytinyağı, süt, kaymak, tereyağı, şeker, su ve } \\
\text { limon suyu. }\end{array}$ & (Işık, 2006) \\
\hline & Sütlü Selemen & Süt, şeker, un ve yumurta & (Işık, 2006) \\
\hline & Badem helvası & $\begin{array}{l}\text { Badem (kabuksuz), tereyağı, zeytinyağı, un, şeker, gül } \\
\text { suyu, su }\end{array}$ & (Işık, 2006) \\
\hline
\end{tabular}




\begin{tabular}{|c|c|c|c|}
\hline & Nişasta Helvası & Nişasta, şeker, su ve tereyağı. & (Işık, 2006) \\
\hline & Gül reçeli & Kokulu pembe gül, şeker, limon suyu & (Gürkan, 2001) \\
\hline \multirow{3}{*}{ 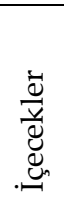 } & & & (Halıc1, 2007) \\
\hline & Sirkencübin & Üzüm sirkesi, bal & \\
\hline & Gül şerbeti & Gül çiçeği yaprağı, su, toz şeker, limon suyu & $\begin{array}{l}\text { (Özükan, Özükan, } \\
\text { ve Öneş, 2002) }\end{array}$ \\
\hline
\end{tabular}

Tablo 1'den de görüldüğ̈̈ üzere Konya mutfağının çorbalarında ağırlıklı olarak mercimek, süzme yoğurt, yarma, nohut, bamya ve salça ağırlıklı olarak kullanılırken, çorbalarda kullanılan baharatlarda nane ve pul biberin varlı̆̆ı dikkati çekmektedir. Etli ve sebze yemeklerine baktığımızda kemikli ve kemiksiz koyun eti, salça, soğan, sadeyağ, havuç, kereviz, erik ve asma yaprağının kullanımı yaygındır. Böreklerinin yapımında ise daha çok kıyma ve tulum/beyaz peynir kullanımı dikkati çekmektedir.

\section{SONUÇ, TARTIŞMA VE ÖNERILER}

Çalışmada gastronomi turizminde öncü olma yolunda ilerleyen ve Selçuklu devletine başkentlik yapan Konya şehrinin tarihe dayanan yöresel yemek ürünlerine bakıldığında; beslenme ile ilgili zengin bir yiyecek ve içecek çeşitliliğine sahip olduğu görülmektedir. Konya ili bölgesinin coğrafi durumunun hem tahıl üretimi hem de küçükbaş ve büyükbaş hayvan yetiştiriciliğine uygun olması ve geçmişte ipek ve baharat yollarının güzergâhının üzerinde bulunması ve sosyo-politik nedenlerden dolayı Konya ili günümüze kadar birçok medeniyete ev sahipliği yapmıştır. Literatürde farklı tarih dönemlerinde bölgede hüküm sürmüş olan Orta Asya Türkleri, Selçuklu ve Anadolu Beylikleri ile Osmanlı devletinin karşılıklı kültürlerarası etkileşimleri sonucunda Konya mutfağının yöresel yemeklerinin, zengin çeşitte, kendine özgü ve sade olmasını sağladığı belirlenmiştir. Konya mutfağının yemek çeşitleri, özellikle et ürünleri (fırın kebabı, tirit) ve tahıl ağırlıklıdır (hamur işleri [etli etmek, bıçak arası, su böreği], tatlılar [sacarası, höşmerim]). Konya' da yemek tüketimi ise sadece günlük ihtiyacın karşılanması olarak görülmemelidir. Literatürde Mevlevi kültüründe mutfak, yemek hazırlamanın yanında bir eğitim kurumu olarak kabul edildiği ve Mevlevi mutfağının hiyerarşik yapıya sahip olan mutfak adabı ve ritüellerinin, Konya yemek kültürünü etkilediğiyle ilgili bulgulara rastlanmıştır.

Literatürde Konya mutfağının bazı yiyecekleri neolitik çağa kadar dayanan Çatalhöyük yiyeceklerinden özellikle mercimek ve bulgur ile Sille yerleşim alanlarındaki yiyecek ürünlerini de (kayısı, üzüm ve pekmez gibi) içerdiği belirlenmiştir. Bu yerel ürünlerin kullanılmasıyla yapılan yemek çeşitleri (mercimekli bulgur pilavı, kayısı yahnisi, calla, pekmezli helva gibi) gastronomi turizmi açısından önem arz etmektedir. Sonuç olarak Konya yöresel yemeklerinin yapılışında tarihi izlerin bulunması ve şehrin kendi yöresel ürünleri üretme kapasitesi olmasıla ve üretilen bu ürünlerle yöresel yiyeceklerin yapılması bölgede gastronomi turizminin ilerlemesinde önemli bir potansiyel oluşturmaktadır. Yine mutfakta kullanılabilecek yöresel ürün çeşidinin fazla olması, lezzetli yemeklerin ve içeceklerin ortaya çıkmasına, bununla birlikte Konya şehrinin gastronomi turizmi bakımından uluslararası marka şehir olması yönünde tanınırlığının artmasına neden olduğu 
ve/veya olacağı düşünülmektedir. Tüm bu açıklamalar ışığında her geçen gün yöresel ürünlerle hazırlanan Konya yöresel yiyeceklerin pazarlama ve tanıtımı sayesinde şehrin gastronomi turizm açısından benzersiz bir kimliğe sahip Konya yöresel yemeklerinin rekabet edilebilirliği daha da artacağı düşünülmektedir. Buna rağmen, geçmişte birçok medeniyetleri bünyesinde barındırmasıyla oluşan etkileşimler sonucunda Konya mutfağına ait yemek çeşitlerinden bazılarının hala tanıtım eksikliklerinin olduğu düşünülmektedir. Bu nedenle Konya ili sınırları içinde yaşayan etnik toplulukların yaptıkları tanınırlığı olmayan yemek reçetelerinin (onaşı, salçalı mantı, asıda vb) tarihi bir inceleme kapsamında araştırılmasıyla gelecekteki araştırmacılar ve/veya yazarlar için yapılacak yeni çalışmalar oluşturabilir. Konya mutfağında yer alması gereken tüm yerel yiyecek ve içeceklerin arşivlenebilmesi için gastronomi ve turizm sektörleriyle ve üniversitedeki bilim insanlarının proje kapsamında iş birliğinin olmasının önem taşıdığı ön görülmüş, gelecek için yapılacak bu çalışmaların Konya gastronomi turizmine büyük fayda sağlayacaktır.

Hakem Değerlendirmesi: Dış bağımsız.

Teşekkür: Katkılarından dolayı hakemlere teşekkür ederiz.

Destek Bilgisi: Herhangi bir kurum ve/veya kuruluştan destek alınmamıştır.

Çıkar Çatışması: Yazarlar arasında çıkar çatışması yoktur.

Etik Onayı: Bu çalışmanın tüm hazırlanma süreçlerinde etik kurallara riayet edildiğini yazar(lar) beyan eder. Aksi bir durumun tespiti halinde Güncel Turizm Araştırmaları
Dergisi'nin hiçbir sorumluluğu olmayıp, tüm sorumluluk makale yazar(lar)ina aittir.

Bilgilendirilmiş Onam Formu: Tüm taraflar kendi rızaları ile çalışmaya dâhil olmuşlardır. Etik Kurul Onayı: Çalışma kamuya açık ikincil verilerin kullanılmasiyla oluşturulmuştur.

Araştırmacıların Katkı Oranı: Yazarlar çalışmaya eşit oranda katkı sağlamıştır.

Veri Kullanılabilirlik Beyanı: Araştırma verileri paylaşılmamıştır.

\section{KAYNAKÇA}

Akın, G., Özkoçak, V. ve Gültekin, T. (2015). Geçmişten Günümüze Geleneksel Anadolu Mutfak Kültürünün Gelişimi. ResearchGate, 33-51.

Akman, M. (2008). Osmanlılar Dönemi Konya Mutfak Kültürü. Haziran 12, 2018 tarihinde www.konyalezzet.com:

http://www.konyalezzet.com/Osmanli_Donemi_Konya_Mutfak_Kulturu_icerik144.ht $\mathrm{ml}$ adresinden alınd 1

Aksoy, M., Akbulut, A. B. ve İflazoğlu, N. (2016). Mevlevilikte Mutfak Kültürü ve Ateşbaz-1 Veli Makamı (Culinary Culture and Atesbaz Veli Chair in Mevleviyeh). Journal of Tourism and Gastronomy Studies, 4/1, 96-103.

Arsel, S. (1999). Eskimeyen Tatlar Türk Mutfak Kültürü. İstanbul: Vehbi Koç Vakfı.

Batu, A. (2016). Kültür ve Gastronomi Turizmi Bakımından Konya. Akademik Sosyal Araştırmalar Dergisi, Y1l: 4, Sayı: 30, Eylül 2016, 20-38.

Bekleyiciler, N. (2015). Ateşbaz-1 Veli. Üstüniş Ofset Matbaa, Konya.

Bilgin, A. ve Samancı, Ö. (2015). Türk Mutfağı. Ankara: Kültür ve Turizm Bakanlığı. 
Bulut-Solak, B. (2016). Sürdürülebilir Gastronomi Turizmine Bir Model: Sille Beldesi Örneği. Gazi Üniversitesi Turizm Dergisi, 1, 1-12.

Büyükşalvarcı, A., Şapcılar, M. C. ve Yılmaz, G. (2016). Yöresel Yemeklerin Turizm İşletmelerinde Kullanılma Durumu: Konya Örneği. Journal of Tourism and Gastronomy Studies, 4(4), 165-181.

Ceylan, F. ve Yaman, M. (2018). Ritüele Dönüşen Mutfak: Mevlevi Mutfağı. İnsan ve Toplum Bilimleri Araştirmalari Dergisi, 3 (7), 2172-2179.

Çalışkan, O. (2013). Gastronomic Identity in Terms of Destination Competitiveness and Travel Motivation, Journal of Tourism and Gastronomy Studies. Journal of Tourism and Gastronomy Studies, 40-51.

Düzgün, E. ve Durlu-Özkaya, F. (2015). Mezopotamya'dan Günümüze Mutfak Kültürü. Journal of Tourism and Gastronomy Studies 3/1 (2015) 41-47, 43.

Eken, V. ve Bulut-Solak, B. (2018). Konya'nın Yöresel Yemeklerine Tarihi Bir Bakış. 2nd International West Asia Congress of Tourism Research (s. 65-66). Van: Paradigma Akademi Basın Yayın Dağıtım.

Ertaş, M., Bulut-Solak, B. ve Kılınç, C. Ç. (2017). Konya'da Mevlevi Mutfağı Yiyeceklerinin Gastronomi Turizminde Canlandırılması. Gazi Üniversitesi Turizm Dergisi, 52-70.

Güler, S. (2016). Türk Mutfak Kültürü ve Yeme İçme Alışkanlıkları. Dumlupınar Üniversitesi Sosyal Bilimler Dergisi, Sayı 26., 24-30.

Gürkan, O. T. (2001). Yöresel Türk Mutfağı. İstanbul: Yaylım Yayıncllık.

Gyimothy, S., Rassing, C. R. ve Wanhill, S. (2000). Marketing Works: A Study of Restaurants on Bornholm. Denmark. International Journal of Contemporary Hospitality Management, 371-379.

Halıcı, N. (2005). Konya Yemek Kültürü ve Konya Yemekleri. İstanbul: Rumi Yayınları.

Halıcı, N. (2007). Mevlevi Mutfağı. İstanbul: Metro Kültür Yayınları.

Halıcı, N. (2011). Konya Mutfağı. Konya: Selçuklu Belediyesi Kültür Yayınları.

Halıcı, N. (2013). Geçmişin İzleriyle Sille Mutfağı. Konya: Selçuklu Belediyesi Yayınları.

Işık, A. (2006). Konya Mutfak Kültürü ve Konya Yemekleri. Konya: Konya Valiliği İl Kültür ve Turizm İl Müdürlüğü.

Joppe, M., Martin, D. W. ve Waalen, J. (2001). Toronto's Image As a Destination: A Comparative Importance-Satisfaction Analysis by Origin of Visitor. Journal of Travel Research, 252-260.

Karaman, A. ve Bağcıoğlu, S. (2014). Gastronomi Turizmi ve Konya İline Ait Gastronomik Değerler. Sosyal Bilimler Meslek Yüksekokulu Dergisi, 135.

Kastenholz, E., Davis, D. ve Paul, G. (1999). Segmenting tourism in rural areas: the case of north and central Portugal. Journal of Travel Research, 353-363.

Kızıldemir, Ö. ve Sarışık, M. (2014). Türk Mutfak Kültürünün Tarihsel Gelişiminde Yaşanan Değişimler. AİBÜ Sosyal Bilimler Enstitüsü Dergisi, 14(13), 191-210.

Kivela, J. ve Crotts, J. C. (2005). Gastronomy Tourism: A Meaningful Travel Market Segment. Journal of Culinary Science and Technology, 4 (2/3), 39-55. 
Kivela, J. ve Crotts, J. C. (2006). Tourism and Gastronomy: Gastronomy's Influence on How Tourists Experience a Destination. Journal of Hospitality and Tourism Research, 30 (3), 354-377.

Konyalı, İ. H. (1964). Abideleri ve Kitabeleri İle Konya Tarihi. Konya: Yeni Kitap Basımevi.

Koz, M. S. (2002). Yemek Kitabı. İstanbul: Kitabevi.

Odabaşı, A. S. (2001). Konya Mutfak Kültürü. Konya: Konya Ticaret Odası.

Ögel, B. (1978). Türk Kültür Tarihine Giriş IV. Ankara: Kültür Bakanlığı Yayınları: 244 .

Özkanlı, O. ve Tekin, A. R. (2006). Eski ve Yeni Mahsul Sumak Tanelerinin Su Soğurma İzotermlerinin Modellenmesi. Gıda Teknolojisi Derneği, 331-334.

Özükan, B., Özükan, N. ve Öneş, M. (2002). 500 Yıllık Osmanlı Yemek Kültürü, Günümüze Uyarlanmış 99 Osmanlı Yemeği,. İstanbul: Boyut Yayın Grubu.

Sadıkoğlu, N., Yerlikaya, A. D., Funda, B., ve Cumalı, S. (1999). Lezzetli Yeşiller. İstanbul: Hürriyet Gazetecilik ve Matbaacılık.

Sarıköse, B. (2009). Sille: bin yıllık birliktelik,tarihçesi ve sosyo-ekonomik yapısı. Konya: Çizgi Kitabevi.

Seçim, Y. ve Esen, M. D. (2020). Konya Mutfağında Yer Alan Yöresel Yemeklerin İşletme Menülerinde Yer Alma Düzeylerinin Tespit Edilmesi. Afyon Kocatepe Üniversitesi Sosyal Bilimler Dergisi, 279-294.

Shenoy, S. (2005). Food Tourism and The Culinary Tourist. Clemson University Unpublished $\mathrm{Ph}$.

Soysal, S. (2007). Derviş Sofraları. İstanbul: Doğan Egmont Yayıncılık ve Yapımcılık Tic. A.Ş.

Sürücüoğlu, M. S. ve Özçelik, A. Ö. (2007). Türk Mutfak ve Beslenme Kültürünün Tarihsel Gelişimi. Haziran 11, 2018 tarihinde Atatürk Kültür Dil ve Tarih Yüksek Kurumu: http://www.ayk.gov.tr/wp-content/uploads/2015/01/SÜRÜCÜOĞLU-Metin-SaipÖZÇELIK-Ayşe-Özfer-TÜRK-MUTFAK-VE-BESLENME-KÜLTÜRÜNÜNTARİHSEL-GELIŞİMİ.pdf adresinden alındı

Tosun, N. (2004). Tasavvuf Kültüründe Tekke Yemekleri. Tasavvuf İlmi ve Akademik Araştırma Dergisi, 5(12), 123-135.

Uzunağaç, Ö. (2014, 7 21). Selçuklu Anadolu'sunda Beslenme ve Yemek Kültürü. Selçuklu Anadolu'sunda Beslenme ve Yemek Kültürü. İstanbul.

Yetiş, Ş. A. (2015). Kapadokya Yemek Kültürü ve Mustafapaşa Beldesi: Sinasos Örneği. Journal of Tourism and Gastronomiy Studies, 12-19. 